\title{
The Importance of High Nature Value Areas in the Development of the Rural Areas of Lower Silesia
}

\author{
Joanna SZYMAŃSKA ${ }^{1, *}$, Pavel JEDLICKA ${ }^{2}$ \\ 1 Wrocław University of Economics and Busines, Wrocław, Poland; joanna.szymanska@ue.wroc.pl \\ 2 Hradec Kralove University, Hradec Kralove, Czech Republic; pavel.jedlicka@uhk.cz \\ * Correspondence: joanna.szymanska@ue.wroc.pl
}

\begin{abstract}
The purpose of this article is to diagnose the state of resources of natural areas under legal protection and to attempt to assess the importance of naturally valuable areas for rural development in the province Lower Silesia in 2005-2018. This study uses desk research methods: descriptive, analytical, and mathematical and statistical (using Excel software). It presents the use pattern of the total area of these lands, according to the forms of protection of their area and subregions administratively separated in this voivodeship. It pays attentions to selected possibilities of multifunctional rural development in Lower Silesian Voivodeship, the source of which are the values of the local natural environment. Analysis of source data showed that in Lower Silesia the total area of naturally valuable areas increased, which are under legal protection. Such areas contribute to the multifunctional development of villages and agriculture. Based on the analysis of specialized studies, it was found that in the vicinity of valuable natural and landscape areas in Lower Silesia, various forms of innovative tourism are developing (eco-agrotourism, thematic villages) and organic farming. This is a favorable phenomenon for ecological (better climate, greater biodiversity) and socio-economic (new jobs in rural areas) reasons.
\end{abstract}

Keywords: high nature value areas; rural areas; Lower Silesia

JEL Classification: Q0; Q5; R1

\section{Introduction}

High nature value areas include both areas and natural objects under legal protection (national parks, nature reserves, landscape parks, protected landscape areas, Natura 2000 areas, nature monuments, documentation sites, ecological sites, nature and landscape complexes) (Act on nature protection 2020) and those that have not been covered by such protection. One should agree with A. Zielińska that a high nature value area is a broader issue than a protected area (Zielińska 2010).

In Lower Silesian Voivodeship adopted for the research, there are many valuable natural areas and all forms of area and individual protection have been created here (Board of the Lower Silesian Voivodeship...2020; Statistical Office in Wroclaw. 2020. Statistical yearbook of Lower Silesian Voivodeship...2020; Marshal's Office of the Lower Silesian Voivodship. 2020). Geographical location of Lower Silesian Voivodeship makes some valuable natural areas extend beyond Polish borders, to the Czech Republic and Germany.

Numerous areas valuable in terms of nature and landscape, rich mineral water deposits and the largest number of immovable monuments entered in the register of monuments from among all Polish voivodeships (three of them inscribed on the UNESCO World Cultural and Natural Heritage List: the Churches of Peace in Jawor and Świdnica and Centennial Hall in Wroclaw) - make Lover Silesian Voivodeship develop dynamically in terms of various forms of tourism and recreation (Marshal's Office of the Lower Silesian Voivodship 2020).

The purpose of the study is to diagnose the resources of natural areas under legal protection and to attempt to assess the importance of high nature value areas for rural development in Lower Silesian Voivodeship. 
The time horizon of the research covered the years 2005-2018; in a few cases this time range was different due to the availability of reliable source data.

\section{Methodology}

The study uses desk research: descriptive, analytical, mathematical and statistical methods (using Excel software). For the preparation of the article, selected subject literature references, specialized studies and data of universal statistics published in statistical yearbooks titled Environmental protection, Environmental protection in Lower Silesian Voivodeship, Statistical yearbooks of Lower Silesian Voivodeship, were used.

\section{Characteristics of High Nature Value Areas Protected by Law}

High natural value areas cover, according to Zielińska:

- Forms of area protection (traditional forms of protection: national parks, nature reserves; newer forms of protection: landscape parks, protected landscape areas; European forms of protection: Natura 2000 areas).

- Forms of individual protection (nature monuments, documentary stands, ecological lands, nature and landscape complexes).

- Forms of species protection of plants, animals and fungi (Protection of plants, animals and fungi of endangered species in the natural environment. Depending on where the protected species are found, species protection in situ or ex situ is distinguished. In situ protection is the protection of plant, animal and fungal species as well as creations of nature in places of their natural occurrence. Ex situ conservation concerns plant, animal and fungal species outside their natural occurrence. It is run in zoos, botanical gardens or gene banks. Ex situ conservation should aim to restore individuals of these species to the natural environment. Ex situ protection also applies to the protection of rocks, fossils and minerals in places of their storage (Poskrobko, Poskrobko 2012; Nature Conservation Act...2020).

- Botanical gardens, zoos, animal rehabilitation centres.

- Green areas and tree stands.

- Municipal greenery and separate protection zones (e.g. city parks, river valleys), the protection of which is not regulated by the Nature Conservation Act (Zielińska 2010).

In Lower Silesian Voivodeship, the traditional forms of area protection include two national parks (Karkonosze and Stołowe Mountains) were created (as of the end of 2018), both are on the list of the International Union for Conservation of Mature - IUCN-WCU) and 67 nature reserves. The Karkonosze National Park has been inscribed by UNESCO on the list of biosphere reserves (UNESCO research program "Man and Biosphere" - MaB). This reserve has a cross-border character (Polish and Czech Karkonosze Biosphere Reserve). Biosphere reserves are a global form of nature protection. The Karkonosze National Park is also covered by the Convention on Wetlands of International Importance, in particular as the living environment of water birds (the so-called Ramsar Convention). As a result of the implementation of the Convention on Wetlands, the "Ramsar" World Reserve Network is created (Convention of February 2, 1971. Journal of Laws No. 7, item. 24 and item 25). In total, seven national parks are covered by this Convention in Poland (Statistics Poland 2020).

Currently, Lower Silesian Voivodeship has 12 landscape parks and 16 protected landscape areas. The forms of individual nature protection in this voivodship include: nature monuments $(2,579$ of such monuments), ecological sites (167, respectively), nature and landscape complexes (18) and documentation sites (4). In addition, different plants, animals and fungi are under species protection. As noted by Boć, Nowacki, Samborska-Boć, in the scope of legal protection of nature, Poland has traditions that go deep into its history. The area protection, in the form of national parks and nature reserves, was decided relatively early, during the Second Polish Republic (1918-1939). New forms of nature protection were introduced only at the turn of the 1970s and 1980s. That was also the time of the qualitative and quantitative broadening of the scope of individual nature protection forms in Poland (Boć et al. 2004). 
There are also designated Natura 2000 Areas, the purpose of which is to maintain biodiversity by protecting not only the most valuable and rarest elements of nature, but also the most typical, still widespread natural systems that are characteristic of given biogeographic regions. The NATURE 2000 European Ecological Network began to be introduced in Poland in the early 2000s. These are areas of importance for the European Union, protected in order to preserve natural habitats and species that are important from a supranational (European) point of view, connected by a network of ecological corridors. The NATURA 2000 area, designated in a given biogeographical region, should significantly contribute to the preservation or restoration of the characteristics of that region or ensuring the protection of the species of interest to the European Union (Poskrobko, Poskrobko 2012).

The NATURA 2000 Area Network includes Special Protection Areas of Birds (SPAs) and Special Areas of Habitat Protection (SACs). In the analysed years 2005-2018, their area increased significantly. SPAs areas increased to 292,801.8 ha (3.6 times), and SACs to 354,732.4 ha (increase up to 9.4 times). In total, the acreage of these areas in Poland (SPAs and SACs) increased less dynamically than in Lower Silesian Voivodeship (respectively: 1.6 times and 3 times).

In 2018, the SPAs area constituted 14.7\% of the total area of Lower Silesian Voivodeship (by 10.7 percentage points more than in 2005), while SACs respectively $17.8 \%$ of the voivodeship's area (i.e. more by 15.9 percentage points). For comparison, in the corresponding period SPAs in Poland occupied $15.7 \%$ of the total area of the country, while SACs $-11.2 \%$. In 2018 , compared to 2005 , the area of both types of these sites increased by 5.8 percentage points and 7.4 points percent, respectively.

In the analysed years 2005-2018, the total area of high nature value areas, covered by legal protection, in Lower Silesian Voivodeship increased to 371, 513.7 ha (by 2.7\%). The trend in this respect can be described by the equation for the trend line (equation of the polynomial trend line: $y=-0.5525 x^{6}$ $+24.808 x^{5}-421.54 x^{4}+3335.3 x^{3}-12150 x^{2}+18532 x+352437$; fitting the trend to data $R^{2}=0.9589$ ) (Figure $1)$.

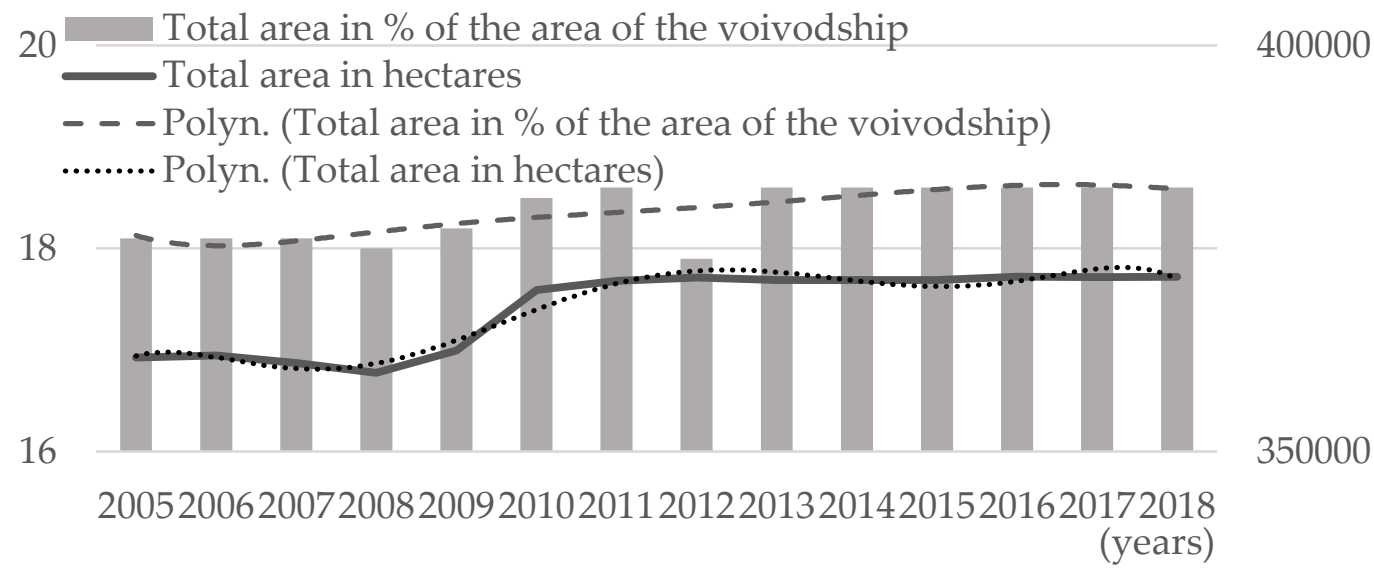

Figure 1. General area of special natural values objects legally protected in Lower Silesian Voivodship in the years 2005-2018 (ha, \% of the voivodship's area).

Among the types of areas with special natural values legally protected in Lower Silesian Voivodeship, in the analysed years 2005-2018:

- The area increased, ranking this growth in descending order, in the case of: nature and landscape complexes (up to 6 times, to $9472.4 \mathrm{ha}$ ), ecological sites (by $9.1 \%$, to $5242.5 \mathrm{ha}$ ), nature reserves (by 3.3\%, up to 10,677.3 ha), national parks (by $3.2 \%$, up to $12,303.5 \mathrm{ha}$ ) and protected landscape areas (by $1.6 \%$, up to $138,420.6$ ha).

- However, the area of landscape parks decreased (by 0.7\%, to 195,397.4 ha).

As a result, the share of the total area of high nature value areas in the total area of Lower Silesian Voivodeship increased, up to $18.6 \%$ in 2018 (by 0.5 percentage point, compared to 2005). Equation of the polynomial trend line $\left(y=6 \mathrm{E}-06 \mathrm{x}^{6}-0.0003 \mathrm{x}^{5}+0.006 \mathrm{x}^{4}-0.0603 \mathrm{x}^{3}+0.3101 \mathrm{x}^{2}-0.6889 \mathrm{x}+18.561\right.$; fitting the trend to $\mathrm{R}^{2}=0.5831$ ).

In 2018 general area of high nature value lands per one inhabitant of Lower Silesian Voivodeship was $1,281 \mathrm{~m}^{2}$ and was larger, by $29 \mathrm{~m}^{2}$ than in 2005 , with simultaneous increase in the population to 2.9 million people. 
The largest average annual share (for the years 2005-2018) in the total area of special natural values objects that are under legal protection in the Lower Silesian Voivodeship was the one of landscape parks $(53.2 \%)$, relatively large areas of protected landscape $(37.5 \%)$, and much smaller in the case of national parks $(3.3 \%)$, nature reserves $(2.9 \%)$, nature and landscape complexes $(1.7 \%)$, while the smallest was the share of ecological sites (1.4\%) (Figure 2).

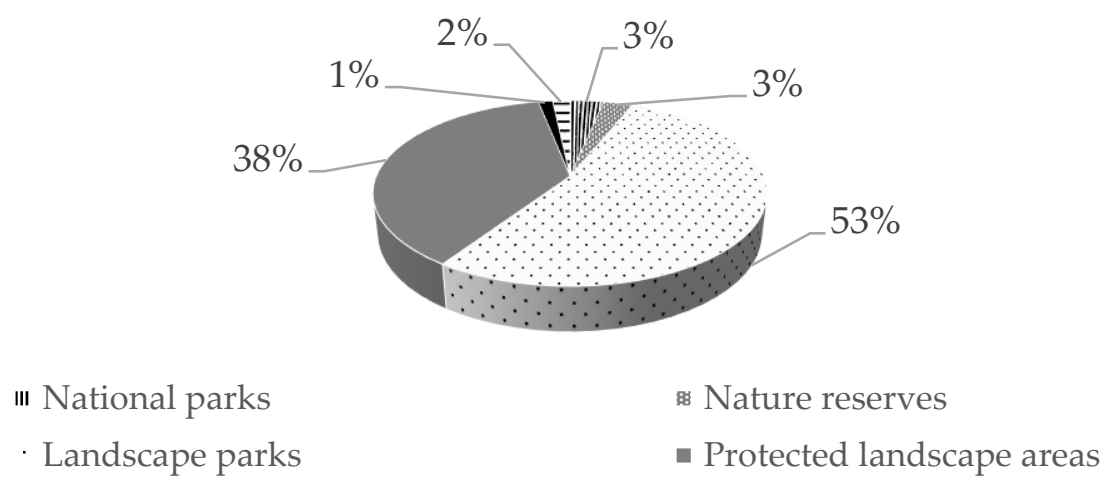

Figure 2. The average annual structure of the total area uses in respect to special natural value objects legally protected in Lower Silesian Voivodeship for 2005-2018, by type of area (\%).

The structure of the use of the total surface of special natural value areas legally protected in Lower Silesian Voivodeship was analysed according to administratively separated subregions. The analysis shows that Wrocław Subregion has the largest average annual share of the total surface of areas with special legally protected natural values in their total area in Lower Silesian Voivodeship (31.4\%). The analysed indicator for Wałbrzych Subregion (27.7\%) has a slightly smaller value, and significantly smaller for Legnica-Głogów $(22.9 \%)$ and Jelenia Góra $(17.5 \%)$ subregions. The city of Wrocław has relatively the smallest share (0.5\%) (Figure 3).

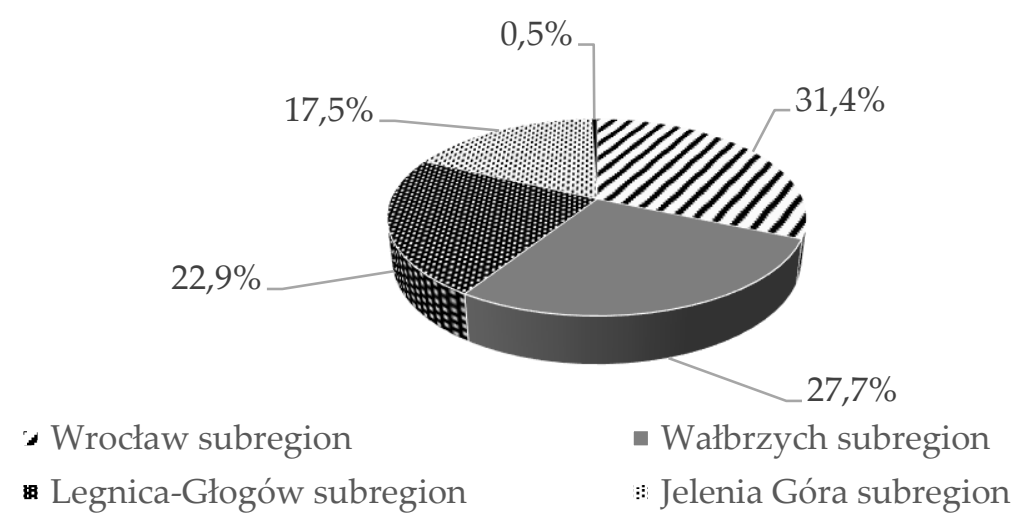

Figure 3. The average annual structure of the total area uses in respect to the areas with special natural values legally protected in Lower Silesian Voivodeship by subregions of Lower Silesian Voivodeship (\%).

National parks in Lower Silesian Voivodeship were established within its two subregions (Jelenia Góra and Wałbrzych Subregions), out of five administratively separated in this voivodeship. The area occupied by both of them is similar. The share of the area of the Stołowe Mountains National Park in the total area occupied by this form of nature protection in Lower Silesian Voivodeship is slightly larger than in the case of the Karkonosze National Park (51.6\% versus $48.4 \%$, respectively). Nature reserves occur in four subregions of Lower Silesian Voivodeship (they were not created only in the city of Wrocław Subregion). The largest share in the total area of nature reserves created in this voivodship have those located in Wrocław Subregion (59.3\%), definitely smaller in Legnica-Głogów $(16.4 \%)$, Jelenia Góra (14.3\%) and Wałbrzych Subregions (10\%). Most of the area of nature reserves in Wrocław Subregion is occupied by the "Milickie Ponds " Nature Reserve. It is a unique ornithological 
reserve on both Polish and European scale where carp breeding is carried out. In 1995, this reserve was entered on the list of protected areas under the RAMSAR Convention, and in 2000 it was included on the Living Lakes program list as one of the unique water areas in the world (this list includes Lake Baikal and the Dead Sea). The "Milickie Ponds" nature reserve is part of the "Barycz Valley" Landscape Park. It is a nesting area for about 166 species of birds, another 108 species of birds appear there during migrations. In this respect, this reserve is comparable with the Biebrza National Park (Provincial Inspectorate for Environmental Protection in Wroclaw. 2020. Report on the state of the environment of Lower Silesian Voivodship...2020).

The "Sulistrowicka Meadow" Reserve is also considered by specialists to be one of the most valuable nature reserves located in Wrocław Subregion. This floristic reserve aims to protect the midforest meadows with all the richness of plant species found there. It is located in the Ślęża Massif (Report on the ... 2007). One of the most valuable nature reserves in Lower Silesian Voivodeship are also those located in Jelenia Góra Subregion ("Ostrzyca Proboszczowska" and "Myśliborski Gorge" Nature Reserves) as well as in Legnica- Głogów Subregion ("Przemkowskie Ponds" Nature Reserves). The "Ostrzyca Proboszczowska" nature reserve - a floristic reserve; it was also created to preserve a prehistoric relic - an extinct, Tertiary volcano. The "Myśliborski Gorge" nature reserve - a floristic reserve the purpose of which is to protect the stand of a fern - Phyllitis scolopendrium - which is the only site of this kind in the Sudety Mountains. The "Przemkowskie Ponds" nature reserve - a fauna reserve; there are 250 species of birds, including approx. 150 breeding ones. Since 2018, this reserve has been part of the NATURA 2000 Area (Board of the Lower Silesian Voivodeship...2020; Provincial Inspectorate for Environmental Protection in Wroclaw. 2020. Report on the state of the environment of Lower Silesian Voivodship...2020).

Landscape parks have been created in the area of all administratively separated subregions in Lower Silesian Voivodeship. The largest share in the total area of landscape parks created in this voivodship have those located in Wrocław Subregion (44\%), smaller in Jelenia Góra $(26.1 \%)$ and Wałbrzych Subregions (24.2\%), definitely smaller in Legnica- Głogów (5.4\%), while the smallest in the city of Wrocław Subregions (0.3\%) (Figure 4 ).

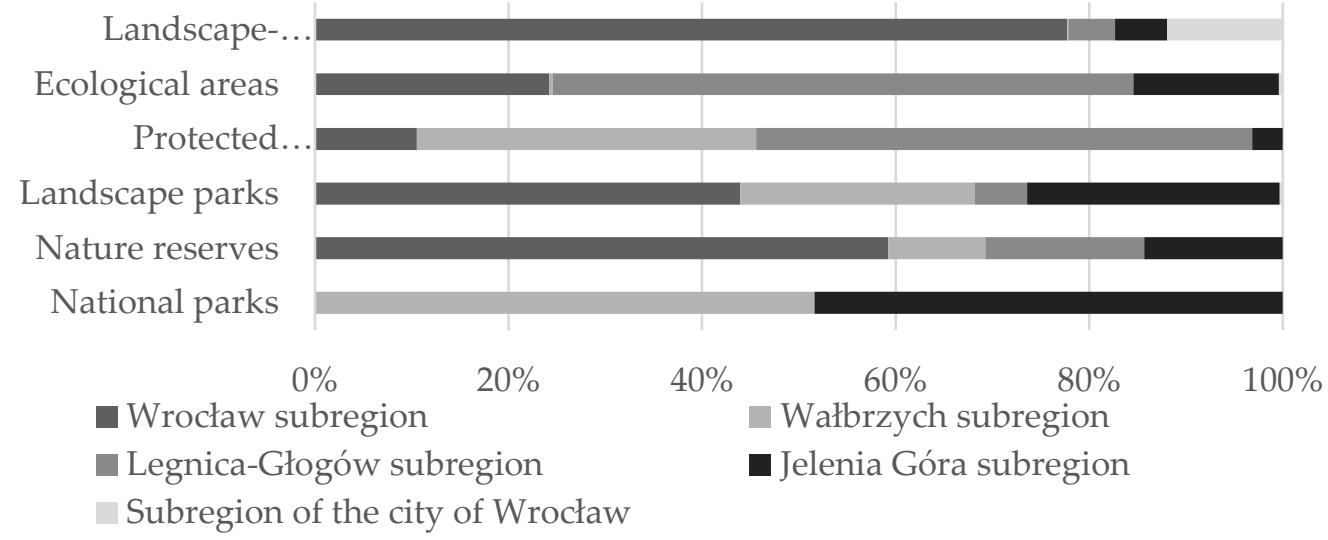

Figure 4. The average annual structure of the total area use of special natural value areas legally protected in Lower Silesian Voivodeship by subregions of Lower Silesian Voivodeship and the type of areas with special natural values protected by law $(\%)$.

Most of the area of landscape parks in the Wrocław Subregion is occupied by the "Barycz Valley" Landscape Park (partly located in the Greater Poland Voivodeship). It includes three types of habitats, namely: fish ponds, wet meadows and forests. Important Bird Areas (IBA) as well as SPAs and SACs have been designated in this park as part of the NATURA 2000 Area. Within the " Barycz Valley" Landscape Park, there is the largest fish pond complex in Europe - consisting of almost 300 ponds. It is worth mentioning that the first ponds in this area were built by the Cistercians as early as the 13th century. Currently, there are mainly carp ( $90 \%$ of production), but also grass carp, silver carp, tench, zander, catfish, pike, Prussian carp, roach and perch cultures here. In the area of the "Barycz Valley" Landscape Park there are nature reserves ("Wydymacz", "Radziądz", "Olszyny Niezgodzkie", "Milickie 
Ponds", "Joanna's Hill") (Provincial Inspectorate for Environmental Protection in Wroclaw. 2020. Report on the state of the environment of Lower Silesian Voivodship...2020).

Protected landscape areas occur in four subregions (they were not created only in the Subregion of the city of Wrocław). The largest share in the total area of protected landscape areas have those created in Legnica-Głogów Subregion (51.3\%), smaller in Wałbrzych Subregion (35\%) followed by Wrocław Subregion (10.5\%), and the smallest share is recorded in Jelenia Góra Subregion (3.2\%). Protected landscape areas have been created in the regions of special landscape values that have tourist and recreational significance and can also act as ecological corridors. Only those of protected landscape areas that are created by an ordinance of a voivode or a resolution of the commune council (landscape parks only by an ordinance of a voivode, like nature reserves) are included in spatial development plans (Nature Conservation Act...2020). In turn, agricultural and forestry lands and other real estate located within the boundaries of the landscape park is left for economic use. However, so-called vicinities (protection zones designated individually, securing against external threats resulting from human activity), similar to those around national parks and nature reserves, may be established.

Ecological sites and nature and landscape complexes were created in all subregions of Lower Silesian Voivodeship. Such complexes are fragments of the natural and cultural landscape that deserve protection due to their scenic or aesthetic values.

In addition, within the boundaries of Lower Silesian Voivodeship, there are objects created in order to provide ex-situ conservation of endangered species of plants, animals and fungi in the natural environment. These include two arboretums (Arboretum in Wojsławice and S. Białobok Forest Arboretum in Ślizów), the Botanical Garden of the University of Wrocław, the Municipal Zoological Garden and the Gene Bank in Kostrzyca. There are also: Forest Promotional Complex "Rychtalskie Forests" and Forest Promotional Complex "Sudety", which are compact forest areas created for the promotion of pro-ecological forest policy of the state.

As specialists emphasize, in terms of biodiversity and the rank of landscape values, Lower Silesian Voivodeship is one of the most attractive regions in Poland (Provincial Inspectorate for Environmental Protection in Wroclaw. 2020. Report on the state of the environment of Lower Silesian Voivodship...2020).

\section{Some Possibilities of Using the Assets of High Nature Value Areas}

Areas valuable in terms of nature and landscape features as well as cultural values (especially material heritage resources) that occur in Lower Silesian Voivodeship are conducive to the development of various forms of tourism and recreation, including their innovative forms (e.g. ecoagritourism, theme villages, educational farms) and organic farming, as it is in general in Poland and the European Union. They stimulate multifunctional and sustainable development of villages and rural areas (Marshal's Office of the Lower Silesian Voivodship. 2020. Development strategy of Lower Silesian Voivodship 2020...2020; Zielińska 2013, Lower Silesian Agricultural Advisory Center. 2020. The state and development of agritourism in Lower Silesia...2020) in terms of the number of immovable monuments entered in the register of monuments, Lower Silesian Voivodeship occupies the first position in Poland, over 83,000 historic buildings. The churches of Peace in Jawor and Świdnica as well as Centennial Hall in Wrocław have been entered on the UNESCO World Cultural and Natural Heritage List. The highest share in national resources $(24 \%)$ is held by residential complexes located in this voivodship - castles and palaces, including the largest on the regional scale castle in Książ near Wałbrzych, and the accompanying historic facilities of shaped greenery - parks and gardens $(12 \%)$ (Marshal's Office of the Lower Silesian Voivodship. 2020. Development strategy of Lower Silesian Voivodship 2020...2020).

According to estimates, currently there are over 600 agritourism farms in Lower Silesian Voivodeship. Compared to the beginning of the 1990s (23 agritourism farms in 1993), their number increased dynamically, which can be described by the equation of the trend line (equation of the trend line: $y=-0.0923 x^{6}+3.4408 x^{5}-5.135 x^{4}+384.85 x^{3}-1534.5 x^{2}+3063.6 x-1841.8$; fitting of the trend to data $\mathrm{R}^{2}=0.9977$ ) (Figure 5). Most of these farms are located in the mountain and foothill areas of the voivodeship, in the vicinity of high nature value areas. 


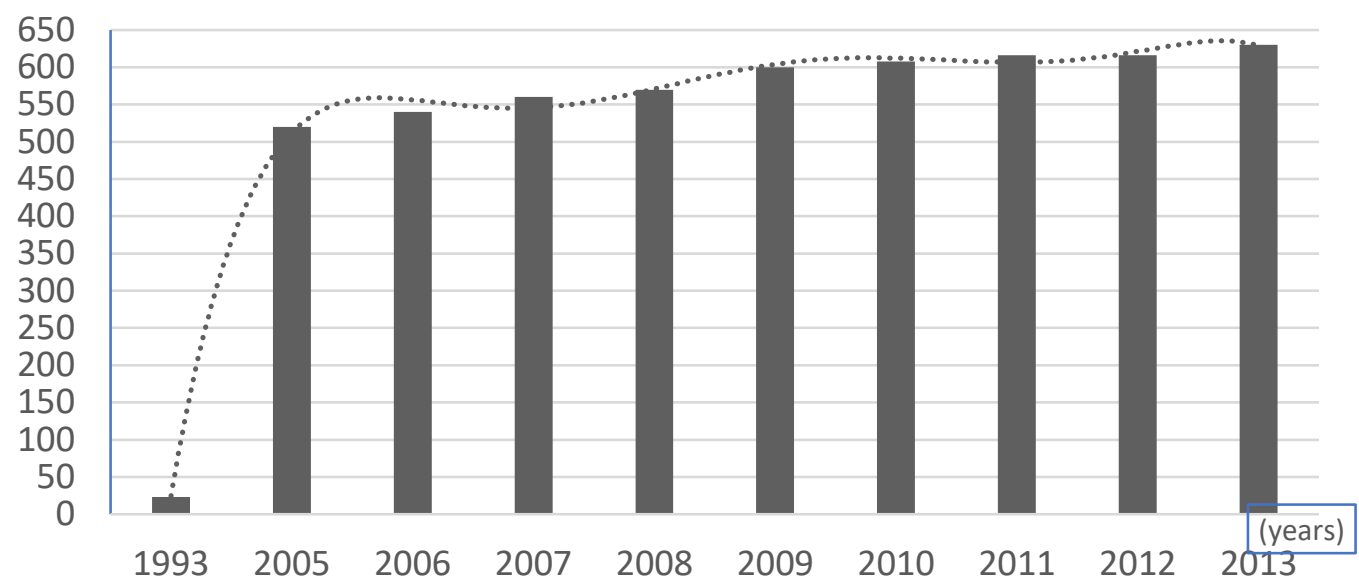

Figure 5. Number of agritourism farms in Lower Silesian Voivodeship in 1993 and in the years 2005-2013.

The advantage of these rural quarters is their offer enriched with homemade food, the possibility of horse riding, carriage rides, participation in sleigh rides with torches. Joint mushroom picking, art workshops and other events are organized (Lower Silesian Agricultural Advisory Center. 2020. Lower Silesian agritourism catalog...2020). The source of supply for these farms with products are very often raw materials obtained from their own crops, farmed using environmentally friendly methods (ecological farms) or bought from the neighbours running such farms (eco-agritourism).

One should agree with the thesis that the strength of agritourism farms in Lower Silesia comes from its proximity to the Czech Republic and Germany. Tourists from Germany are frequent guests in such accommodation facilities, and this is often due to their sentiment to these areas (until World War II these areas belonged to Germany) (Kurtyka-Marcak, Kropsz-Wydra 2014).

In the analysed years 2005-2018 the number of organic farms in Lower Silesian Voivodeship increased, to 713 (by $81.4 \%$ ), the area of their ecological agricultural land grew to 27,357 ha (by $95.8 \%$ ). Nonetheless, multidirectional mid-term fluctuations (increase-decrease fluctuations) are observed. After the initial increase (2005-2011), both the number of these farms and the analysed area of land decreased (2011-2018). In the years 2005-2011 the number of organic farms increased to 1322 (3.4-fold increase), while the area of ecological agricultural land occupied by them increased to 45,546 ha (3.3 times, respectively). In the subsequent examined period (2011-2018), the number of organic farms decreased to 713 (decrease by $46.1 \%$ ), while the area of ecological agricultural land occupied by them decreased to 27,357 ha (decrease by $39.9 \%$ ). There were similar trends in Poland in general, which is unique in Europe. Changes in the considered area in Lower Silesian Voivodeship can be presented in the form of a polynomial trend lines (the equations of the polynomial trend lines take the following forms: Number of organic farms: $y=-0.013 x^{6}+0.5563 x^{5}-8.5749 x^{4}+55.93 x^{3}-147.32 x^{2}+271.44 x+$ 216.24; fitting of the trend to data $R^{2}=0.9955$; Area of organic farm: $y=-0.9056 x^{6}+41.323 x^{5}-711.96 x^{4}$ $+5732.9 x^{3}-22101 x^{2}+41674 x-10785$; fitting of the trend to data $\left.R^{2}=0.9442\right)$ (Figure 6).

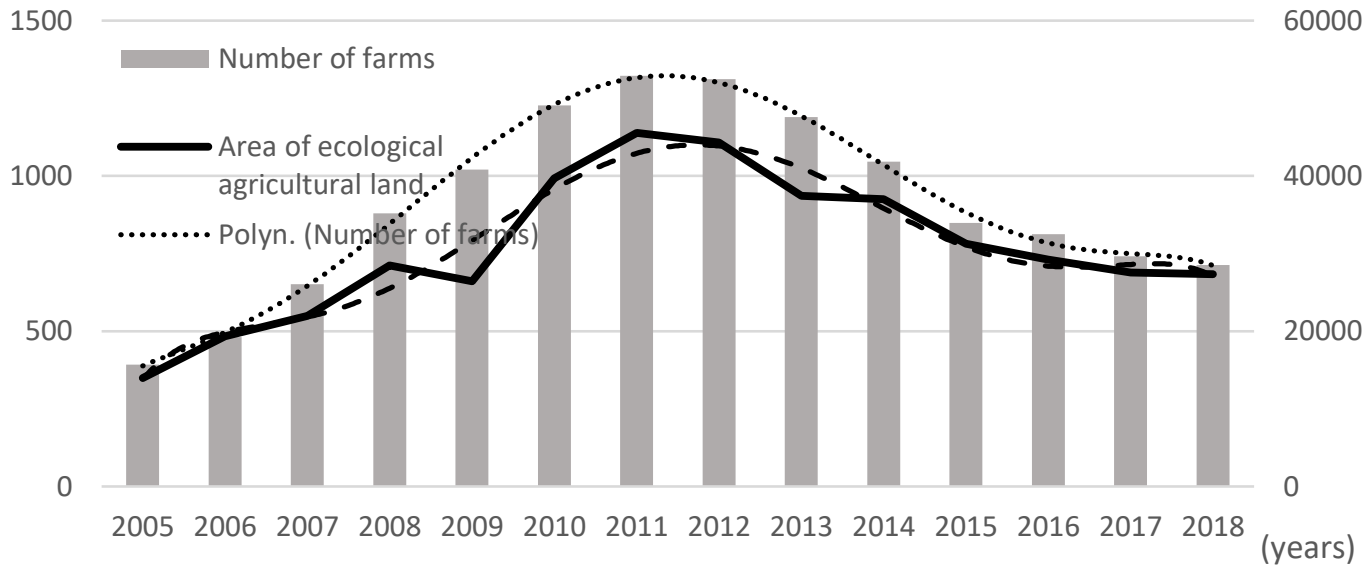

Figure 6. Organic farms in Lower Silesian Voivodeship in 2005-2018 (farms, ha). 
According to the Report on the Commercial Quality Inspection of Agricultural and Food Products, the decrease in the number of organic farms and the area they occupy i results from a combination of many factors. They include, in particular, the lack of successors in the situation of retirement of the current host; difficulties in selling raw materials for organic processing plants, and as a result difficulties in obtaining profitability of production, with its relatively small scale; lack of employees (higher human labour input in organic farms); the lack of production directed to the market and the use of subsidies as the only source of income that would expire with the end of rural development programs from which such farms are supported (BioKurier. pl. 2020. The number of organic farms in Poland is decreasing...2020).

One of the innovative forms of rural tourism includes thematic villages, the most of which, when compared to the administrative units in Poland, were created in Lower Silesia Voivodeship (over 68). Such villages are often based on local natural, cultural or historical resources (in Lower Silesia, e.g. historical, educational and natural paths along the trail of stone crosses in Czaple in the Land of extinct volcanoes).

Among the innovative forms of rural tourism, usually of weekend-break type (several-hour stays), educational farms can also be mentioned. Educational farms - an enterprise based on European experience, established on the initiative of the Agricultural Advisory Centre in Brwinów on behalf of the Ministry of Agriculture and Rural Development. It comprises the network of educational farms located in rural areas throughout Poland. The main purpose of educational farms is to raise the prestige of the farmer's profession and to disseminate knowledge about the origin of food, diversify nonagricultural activities in rural areas, and preserve the cultural heritage of the village. In Lower Silesian Voivodeship they are concentrated in mountain and foothill areas (Agricultural Advisory Center in Brwinów. 2020. Catalog of educational farms 2015...2020).

They contribute to economic recovery of the village, integration of the local community and increase of self-esteem of the village inhabitants. Thematic villages and educational farms primarily create new jobs in the countryside, skilfully using various types of resources, including valuable natural and cultural ones. They can also contribute to the professional and social activation of older rural residents. Such an initiative is an opportunity to obtain external funds and new partners interested in rural development. As a result, it brings measurable socio-economic effects. Most of the thematic villages and educational farms create their tourist product based on regional gastronomic and agricultural products, including those from organic farms (Idziak 2008; Kłoczko-Gajewska 2015; Sala 2016; National portal of thematic villages 2020).

The protection of high nature value areas in the European Union is financially supported by a special fund, the LIVE Financial Instrument. The LIVE Financial Instrument aims to support The 7th Environmental Protection Action Program, which sets out the tasks of the European Union's environmental policy. The priority objectives of the Seventh Program are: protection, preservation and improvement of the Union's natural capital; transforming the Union into a resource-efficient, green and competitive low-carbon economy; protecting Union citizens against environmental pressures and threats to health and well-being; maximizing the benefits of environmental legislation, improving knowledge and evidence base in the field of environment and climate protection; securing ecological investments and supporting sustainable cities; better consideration of more coherent environmental policy in activities and effective international challenges regarding the environment and climate (Now the environment pl. 2020. The Seventh EU Action Program for the protection of the environment...2020). As the only one, it focuses entirely on the field of the environment.

\section{Conclusions}

High nature value areas should be considered a broader concept than protected areas. Protected areas are covered in Poland by certain legal provisions, in accordance with the Act on nature protection. Some of the high nature value areas are not covered by such regulations.

Lower Silesia Voivodeship has all forms of nature protection included in Polish legislation, including the ones of international range, extending to the territories of Poland and the Czech 
Republic (e.g. Karkonosze National Park) and numerous areas and objects that were not covered by such forms of conservation but should be considered high nature value areas.

In the analysed years 2005-2018, the total area of high nature value land under legal protection increased in Lower Silesia, just like in Poland in general. As a result, the share of this area in the total area of the studied region increased. This is a positive phenomenon, not only for ecological (environmental), but also for socio-economic reasons.

The richness of the Lower Silesian animate and inanimate nature, and additionally numerous landscape values of many sites and the history of this region affect the development of various forms of tourism, including innovative forms of rural tourism (eco-agritourism, thematic villages or educational farms), which are supported by EU funds. This stimulates the multifunctional and sustainable development of villages and rural areas.

Organic farming is also developing in the analysed region. However, a surprising phenomenon is the observed decrease in the number of organic farms and the area of arable lands they use in Lower Silesian Voivodeship in the examined period. A similar tendency occurs in Poland in a mediocre way and may be considered unique in the whole Europe, where a different phenomenon is observed - an upward trend.

\section{References}

Agricultural Advisory Center in Brwinów. 2020. Catalog of educational farms 2015. Available online: https://www.zagrodaedukacyjna.pl/index.php?option=com_content\&view=article\&id=153\&Itemid=142 (access on 15 January 2020).

BioKurier. pl. 2020. The number of organic farms in Poland is decreasing. Available online: https://biokurier.pl/ekorynek/INUMBER-gospodarstwa-ekologiczne-w-polsce-maleje (access on 21 January 2020).

Board of the Lower Silesian Voivodeship. Voivodship Urban Planning Office in Wrocław. 2020. Ecophysiographic study for the Lower Silesian Voivodship. 2020. Available online: (https://irt.wroc.pl/pliki/ekofizjografia_2005/250/index.html\#zzoom=z (access on 21 January 2020).

Boć Jan, Nowacki Konrad, Samborska-Boć Elżbieta. 2004. Environmental protection. Wrocław: Kolonia Limited.

Idziak Wacław. 2008. To reinvent the village. Theme villages. Koszalin: Alta Press.

Kłoczko - Gajewska Anna 2020. Economic activity of thematic villages in Poland and a preliminary assessment of its effectiveness. Available online: http://www.wne.sggw.pl/czasopisma/pdf/RNR_2015_T102_z3.pdf (access on 15 January 2020).

Kurtyka-Marcak Izabela, Kropsz-Wydra Irena. 2014. Opportunities and barriers to the development of entrepreneurship in the provision of tourist services in rural areas of Lower Silesia. Warsaw: Scientific Yearbooks Association of Agriculture and Agribusiness Economists XVI (4).

Lower Silesian Agricultural Advisory Center. 2020. Lower Silesian agritourism catalog. Available online: https://docplayer.pl/25079690-Dolnoslaski-katalog-agroturystyczny.html (access: 14 January 2020).

Lower Silesian Agricultural Advisory Center. 2020. The state and development of agritourism in Lower Silesia. Available online: https://www.dodr.pl/III/4/2/3/2/1/1.pdf (access on 19 January 2020).

Marshal's Office of the Lower Silesian Voivodship. 2020. Development strategy of Lower Silesian Voivodship 2020.Availableonline:http://www.umwd.dolnyslask.pl/fileadmin/user_upload/Rozwoj_regionalny/SRWD/ SRWD_2020-final.pdf (access on 27 January 2020).

National portal of thematic villages. 2020. Available online: http://wioskizpomyslem.pl (access on 25 January 2020).

Nature Conservation Act. 2020. Journal of Laws 2020, item 55.

Now the environment pl. 2020. The Seventh EU Action Program for the protection of the environment. Available online: https://www.teraz-srodowisko.pl/aktualnosci/Siodmy-program-dzialan-UE-na-rzecz-ochronysrodowiska-175.html (access on 22 February 2020).

Poskrobko Bazyli, Poskrobko Tomasz. 2012. Environmental management in Poland. Warsaw: Państwowe Wydawnictwo Ekonomiczne.

Provincial Inspectorate for Environmental Protection in Wroclaw. 2020. Report on the state of the environment of Lower Silesian Voivodship 2007-2015. Available online: https://www.wroclaw.pios.gov.pl/index.php?dzial=publikacje\&pod=raporty (access on 20 January 2020) . 
Sala Krzysztof. 2020. Thematic villages as an example of innovation in rural tourism. Available online: file: /// C: /Users/Asia/AppData/Local/Temp/Wioski_tematyczne_jako_przyklad_innowacyjnosci.pdf (access on 24.01.2020).

Statistical Office in Wroclaw. 2020. Environmental protection in Lower Silesian Voivodship in the years 2005-2008. Available online: https://wroclaw.stat.gov.pl/publikacje-i-foldery/ochrona-srodowiska/ochronasrodowiska-i-lesnictwo-w-wojewodztwie-dolnoslaskim-w-latach-2013-2016,1,4.html (access on 8 January 2020).

Statistical Office in Wroclaw. 2020. Statistical yearbook of Lower Silesian Voivodeship 2018-2019. 2020. Available online:file://C:/Users/Asia/AppData/Local/Temp/rocznik_statystyczny_wojewodztwa_dolnoslaskiego_201 9_net.pdf (access on 9 January 2020).

Statistical Office in Wroclaw. 2020. Environmental protection and forestry in Lower Silesian Voivodeship in the years 2009-2012. Available online: https://wroclaw.stat.gov.pl/publikacje-i-foldery/ochronasrodowiska/ochrona-srodowiska-i-lesnictwo-w-wojewodztwie-dolnoslaskim-w-latach-2013-2016,1,4.html (access on 8 January 2020).

Statistical Office in Wroclaw. 2020. Environmental protection and forestry in Lower Silesian Voivodship in the years 2013-2016. Available online: https://wroclaw.stat.gov.pl/publikacje-i-foldery/ochronasrodowiska/ochrona-srodowiska-i-lesnictwo-w-wojewodztwie-dolnoslaskim-w-latach-2013-2016,1,4.html (access on 8 January 2020).

Statistics Poland. 2020. Environment protection 2010-2019. Available online: https://stat.gov.pl/obszarytematyczne/srodowisko-energia/srodowisko/ochrona-srodowiska-2019,1,20.html (access on 7 January 2020).

Zielińska Anetta. 2013. Economy in valuable natural areas in Poland in the context of sustainable development. Wroclaw: Publishing House of the Wroclaw University of Economics.

Zielińska Anetta. 2010. The essence of high nature value areas in legal and economic sciences. Scientific Works of the Wroclaw University of Economics 2010 (140). Economics 11, Wroclaw: Publishing House of the Wroclaw University of Economics. 